Jurnal Sains Kesehatan Vol. 24 No. 2 Agustus 2017

\title{
HUBUNGAN PENGETAHUAN DAN ASUPAN ZAT GIZI IBU HAMIL TERHADAP STATUS ANEMIA IBU HAMIL TRIMESTER I DI PUSKESMAS KECAMATAN SETIABUDI
}

\author{
Priccillia Fazha ${ }^{1}$, Laras Sitoayu ${ }^{1}$, Herwanti Bahar ${ }^{1}$ \\ ${ }^{1}$ Program Studi Ilmu Gizi Fakultas Ilmu-Ilmu Kesehatan \\ Universitas Esa Unggul \\ Email : fazhapriccillia@gmail.com
}

\begin{abstract}
ABSTRAK
Tujuan penelitian ini adalah untuk mengetahui hubungan pengetahuan, asupan zat gizi ibu hamil terhadap status anemia ibu hamil di Puskesmas Kecamatan Setiabudi. Responden penelitian ini berjumlah 36 ibu hamil trimester I yang datang untuk melakukan ANC di Puskesmas Kecamatan Setiabudi selama bulan Januari 2017. Penelitian ini dilakukan di Puskesmas Kecamatan Setiabudi dengan desain crosssectional. Uji statistik yang digunakan adalah uji korelasi Rank Spearman. Teknik pengambilan sampel pada penelitian ini adalah dengan purposive sampling. Hasil uji korelasi Spearman menunjukkan bahwa tidak terdapat hubungan antara pengetahuan, asupan protein dan zat besi terhadap status anemia ibu hamil ( $p>0.05)$ dan terdapat hubungan antara asupan vitamin $C$ dan kalsium terhadap status anemia $(p \leq 0.05)$.
\end{abstract}

Kata Kunci : anemia, kalsium, pengetahuan, protein, vitamin $C$, zat besi

\begin{abstract}
The purpose of this study was to determine the relationship of knowledge, nutrient intake of pregnant women against maternal anemia status in Setiabudi sub-district health centers. The respondents of this study totaled 36 first trimester pregnant women who come to ANC in Setiabudi sub-district health centers during January 2017. The study was conducted in Setiabudi sub-district health centers with crosssectional design. The statistical test used is the Spearman rank correlation test. The sampling technique in this research is purposive sampling. Spearman correlation test results showed that there was no correlation between knowledge, the intake of protein and iron to pregnant women anemia status $(p>0.05)$ and there is a relationship between the intake of vitamin $C$ and calcium against anemia status ( $p \leq$ 0.05).
\end{abstract}

Keywords : anemia, calcium, iron, knowledge, protein, vitamin $C$, zink 


\section{A. Pendahuluan}

Anemia merupakan keadaan di mana masa eritrosit dan/atau masa hemoglobin yang beredar tidak memenuhi fungsinya untuk menyediakan oksigen bagi jaringan tubuh. Secara laboratoris, anemia dijabarkan sebagai penurunan kadar hemoglobin serta hitung ertirosit dan hematokrit di bawah normal (Hariwibowo, 2008).

Ibu hamil merupakan salah satu kelompok yang rentan mengalami anemia. Seorang ibu hamil dikatakan mengalami anemia bila kadar Hb-nya di bawah 11 gr/dl. Menurut WHO (2011), secara global prevalensi anemia pada ibu hamil di seluruh dunia adalah sebesar $38.2 \%$. Prevalensi anemia ibu hamil di Asia Tenggara sebesar 41.5\%, Africa $46.3 \%$, Eropa 25.8\%, dan Amerika $24.9 \%$ (WHO, 2015).

Anemia merupakan salah satu penyebab angka kematian ibu di provinsi DKI Jakarta tahun 2012. Berdasarkan Hasil Riset Kesehatan Dasar (Riskesdas) Tahun 2013, prevalensi anemia pada ibu hamil di Indonesia sebesar $37.1 \%$ dan prevalensinya hampir sama antara bumil di perkotaan $(36.4 \%)$ dan di perdesaan (37.8\%). Hal ini menunjukkan angka tersebut mendekati masalah kesehatan masyarakat berat (Severe Public Health Problem) (Kemenkes, 2013).

Hasil laporan Puskesmas Kecamatan Setiabudi tahun 2012 tercatat terdapat $11.05 \%$ ibu hamil anemia dan meningkat di tahun 2015 sebesar 15.92 $\%$. Saat ini, persentase anemia bumil di puskesmas kecamatan setiabudi bulan Januari (9.32\%), Februari 14.6\%), Maret (12.5\%), April (10.8\%), Mei (11.5\%), Juni (11.5\%), Juli (37\%), Agustus (10.1\%), September (9.4\%), Oktober (13.5\%), November (6.2 \%), dan Desember (17.5\%).
Kebutuhan akan zat besi akan meningkat pada masa pertumbuhan seperti pada bayi, anak-anak, remaja, kehamilan dan menyusui. Kebutuhan zat besi juga meningkat pada kasus-kasus pendarahan kronis yang disebabkan oleh parasit (Masrizal, 2007).

Pengetahuan merupakan salah satu faktor yang menstimulasi atau merangsang terhadap terwujudnya sebuah perilaku kesehatan. Apabila ibu hamil mengetahui dan memahami akibat anemia dan cara mencegah anemia maka akan mempunyai perilaku kesehatan yang baik dengan harapan dapat terhindar dari berbagai akibat atau risiko dari terjadinya anemia kehamilan. Perilaku kesehatan yang demikian berpengaruh terhadap penurunan kejadian anemia pada ibu hamil. Ibu hamil yang mempunyai pengetahuan kurang tentang anemia dapat berakibat pada kurangnya konsumsi makanan yang mengandung zat besi selama kehamilan yang dikarenakan oleh ketidaktahuannya (Purbadewi \& Ulvie, 2013).

Ibu hamil membutuhkan asupan gizi membutuhkan asupan gizi yang cukup agar janin yang ada di dalam kandungan bisa tumbuh secara optimal. Maka dari itu, ibu hamil harus mengonsumsi makanan yang bergizi untuk memenuhi kebutuhan ibu dan janin. Kondisi ibu hamil yang kekurangan gizi atau kurang darah akan mempengaruhi kesehatan bayi di dalam kandungan.konsumsi makanan yang cukup dibutuhkan untuk meningkatkan berat badan ibu hamil.

Pada umumnya ibu hamil menderita anemia gizi besi. Kekurangan zat besi di dalam tubuh disebabkan oleh kekurangan konsumsi zat besi yang berasal dari makanan atau rendahnya absorpsi zat besi yang ada di dalam 
makanan. Pada kehamilan dianjurkan banyak mengkonsumsi makanan yang kaya akan zat besi, asam folat, juga vitamin B seperti hati, daging, kuning telur, ikan, susu, kacang-kacangan seperti tempe dan susu kedelai. Serta sayuran berwarna hijau tua seperti bayam dan daun katuk. Selain itu, mengkonsumsi juga jenis makanan yang memudahkan penyerapan zat besi, misalnya makanan yang mengandung banyak vitamin $\mathrm{C}$. Ibu hamil dianjurkan untuk menghindari makanan/minuman yang dapat menghambat penyerapan zat besi, misal kopi dan teh atau susu kalsium (Hapsari, 2014).

\section{B. Metode Penelitian}

Penelitian ini merupakan penelitian analitik dengan menggunakan rancangan cross sectional dengan sampel pada penelitian ini adalah seluruh ibu hamil Trimester I yang datang ke Poli KIA Puskesmas Kecamatan Setiabudi untuk melakukan ANC dan memenuhi kriteria inklusi dan eksklusi. Data primer pada penelitian ini adalah kadar hemoglobin, pengetahuan ibu hamil tentang anemia, dan asupan protein, Fe, Vitamin $\mathrm{C}$, dan kalsium ibu hamil. Data sekunder penelitian ini adalah data mengenai mengenai profil Puskesmas Kecamatan Setiabudi. Penelitian ini menggunakan metode $F F Q S Q$ untuk mengetahui asupan gizi ibu hamil sebulan terakhir. Kuesioner pengetahuan tentang anemia digunakan untuk mengetahui pengetahuan ibu hamil tentang anemia, tanda dan gejala anemia, akibat anemia, bahan makanan yang dapat menghambat dan membantu penyerapan zat besi. Data yang sudah terkumpul dari sampel dilengkapi dan diberi kode untuk mempermudah analisa. Kemudian dilakukan uji normalitas data dan diuji dengan menggunakan korelasi rank spearman.

\section{Hasil Penelitian}

\section{Analisis Univariat}

Gambaran distribusi frekuensi variabel bebas (pengetahuan, asupan protein, zat besi, vitamin C, dan kalsium) dan variabel terikat (status anemia) dapat dilihat pada Tabel 1 berikut ini :

Tabel 1.

Distribusi Frekuensi Pengetahuan, Protein, Asupan Gizi, dan Status Anemia Ibu Hamil di Puskesmas Kecamatan Setiabudi

\begin{tabular}{cccc}
\hline Variabel & Kategori & $\mathrm{N}$ & $\%$ \\
\hline \multirow{2}{*}{ Status Anemia } & Anemia & 12 & 33,33 \\
& Tidak anemia & 24 & 66,67 \\
\multirow{2}{*}{ Pengetahuan } & Kurang & 15 & 41,7 \\
& Kurang & 21 & 58,3 \\
\multirow{2}{*}{ Asupan Protein } & Kurang & 20 & 55,0 \\
& Cukup & 16 & 45,0 \\
\hline \multirow{2}{*}{ Asupan Zat Besi } & Kurang & 34 & 94,4 \\
\multirow{2}{*}{ Asupan Vitamin C } & Cukup & 2 & 5,6 \\
& Kurang & 12 & 33,3 \\
\multirow{2}{*}{ Asupan Kalsium } & Cukup & 24 & 66.7 \\
& Kurang & 36 & 100 \\
\hline
\end{tabular}


Berdasarkan Tabel 1 dapat dilihat bahwa dari 36 ibu hamil, sebanyak $66,67 \%$ tidak mengalami anemia, 58,3\% ibu hamil memiliki pengetahuan baik, $55,0 \%$ memiliki asupan protein cukup 94,4\% memiliki asupan zat besi kurang, $66,7 \%$ memiliki asupan vitamin C cukup, dan seluruh ibu hamil memiliki asupan kalsium kurang dari AKG di Puskesmas Kecamatan Setiabudi.

\section{Analisis Bivariat}

Analisis ini dilakukan guna mengetahui hubungan variabel bebas (pengetahuan, asupan protein, zat besi, vitamin $C$, dan kalsium) dan variabel terikat (status anemia) dapat dilihat pada Tabel 2 berikut ini :

Tabel 2

Analisis Hubungan Pengetahuan, Asupan Gizi terhadap Status Anemia Ibu Hamil di Puskemas Kecamatan Setiabudi

\begin{tabular}{ccc}
\hline Variabel & Koefisien korelasi (r) & p-value \\
\hline Pengetahuan & $-0,125$ & 0,482 \\
Asupan Protein & $-0,311$ & 0,074 \\
Asupan Zat besi & $-0,231$ & 0,189 \\
Asupan Vitamin C & $-0,336$ & 0,052 \\
Asupan Kalsium & $-0,497$ & 0,003 \\
\hline
\end{tabular}

Berdasarkan Tabel di atas, dapat disimpulkan bahwa tidak terdapat hubungan antara pengetahuan ibu hamil terhadap status anemia pada ibu hamil di Puskesmas Kecamatan Setiabudi, terdapat hubungan yang signifikan antara asupan vitamin $\mathrm{C}$ dan kalsium terhadap status anemia pada ibu hamil di Puskesmas Kecamatan Setiabudi, dan tidak terdapat hubungan yang signifikan antara asupan protein dan zat besi terhadap status anemia pada ibu hamil di Puskesmas Kecamatan Setiabudi.

\section{Pembahasan}

Hasil penelitian ini menunjukkan bahwa prevalensi anemia pada ibu hamil trimester I mendekati angka prevalensi Riskesdas tahun 2013 yaitu 37.1\%. Anemia di Indonesia merupakan masalah yang harus segera diatasi.
Sasaran Rencana Pembangunan Jangka Menengah Nasional 2015-2019 menargetkan tejadinya penurunan prevalensi anemia di tahun 2019 menjadi $28 \%$.

Pengetahuan ibu hamil lebih banyak yang memiliki pengetahuan baik yaitu $58.3 \%$. Berdasarkan penelitian yang dilakukan pengetahuan tentang anemia yang baik akan diikuti dengan perilaku tingkat konsumsi protein yang baik (Putri, Syamsianah, \& Mufnaetty, 2013) Selain itu, pengetahuan tentang anemia juga akan mempengaruhi kepatuhan ibu hamil untuk mengonsumsi tablet besi (Bangun, 2013).

Ibu hamil yang mempunyai pengetahuan kurang tentang anemia akan berperilaku negatif, sedangkan ibu hamil yang mempunyai pengetahuan baik akan berperilaku positif dalam hal 
ini adalah perilaku untuk mencegah atau mengobati anemia. Oleh karena itu, diperlukan peningkatan pengetahuan tentang anemia kepada ibu hamil (Purbadewi \& Ulvie, 2013)

Sebanyak $55 \%$ ibu hamil memiliki asupan protein yang cukup. Asupan protein dibutuhkan oleh ibu hamil untuk sintesis sel - sel darah merah agar tidak mengalami anemia. Protein dalam sel darah merah sebagai hemoglobin yang menjalankan peran utama sel darah merah yaitu mengangkut oksigen untuk dilepaskan ke sel - sel yang mengangkut gas karbon dioksida dari sel ke paru - paru untuk dikeluarkan oleh tubuh (Astuti, 2010).

Sebanyak $94.4 \%$ ibu hamil memiliki asupan zat besi kurang. Zat besi merupakan mineral mikro yang paling banyak terdapat di dalam tubuh manusia dan hewan, yaitu sebanyak 3 5 gram di dalam tubuh manusia dewasa. Zat besi mempunyai beberapa fungsi esensial di dalam tubuh yaitu sebagai alat angkut oksigen dari paru - paru ke jaringan tubuh, sebagai alat angkut elektron di dalam sel, dan sebagai bagian terpadu berbagai reaksi enzim di dalam jaringan tubuh (Almatsier, 2009).

Sebanyak $66.7 \%$ ibu hamil memiliki asupan vitamin $\mathrm{C}$ yang cukup. Vitamin $\mathrm{C}$ dapat membantu penyerapan zat besi dalam pencegahan terjadinya anemia, namun apabila zat besi yang dikonsumsi dalam jumlah yang terbatas maka fungsi vitamin $\mathrm{C}$ sebagai enhancer zat besi tidak akan berjalan. Konsumsi sayur dan buah yang kurang akan berpengaruh sayuran dan buah yang merupakan sumber vitamin dan mineral yang baik, terutama vitamin $\mathrm{C}$ dapat meningkatkan absorpsi besi dalam tubuh (Lewa, 2016).
Seluruh ibu hamil pada penelitian ini memiliki asupan kalsium kurang. Kalsium merupakan zat yang dibutuhkan untuk perkembangan tulang dan gigi pada bayi. Kalsium mempunyai peran yang sangat penting bagi pertumbuhsn bayi dalam rahim serta masa pertumbuhan anak - anak. Bayi atau anak - anak yang kekurangan kalsium akan terhambat pertumbuhannya,daya tahan tubuh lemah bahkan mempengaruhi kecerdasan (Bahar, 2014).

Hasil analisis menggunakan uji Rank Spearman menunjukkan tidak terdapat hubungan antara pengetahuan ibu hamil tentang anemia terhadap status anemia ibu hamil dengan nilai $p=$ 0.482 dan nilai $r=-0.125$. Nilai $r$ negatif menunjukkan semakin rendah pengetahuan ibu hamil tentang anemia maka semakin tinggi status anemia ibu hamil.

Tidak terdapat hubungan antara pengetahuan ibu hamil tentang anemia terhadap status anemia ibu hamil trimester I. Hasil penelitian ini sejalan dengan penelitian yang dilakukan oleh Erwin (2013) dengan nilai $p=0,132$.

Penelitian yang dilakukan Erna dan Setiyowati (2003) bahwa tidak terdapat hubungan yang signifikan antara pengetahuan ibu dengan kejadian anemia dengan $p=0.519$. Kurangnya informasi dan pendidikan yang rendah merupakan salah satu faktor yang mempengaruhi pengetahuan seseorang. Dari hasil wawancara yang dilakukan saat penelitian banyak ibu hamil yang belum mengetahui bahaya anemia, dampak anemia, bahan makanan yang bisa menghambat dan membantu penyerapan anemia.

Berbeda dengan penelitan yang dilakukan oleh Elsy Noversiti (2012) 
yang dilakukan di wilayah kerja Puskesmas Air Dingin Kota Padang menyatakan bahwa anemia lebih terjadi pada ibu yang memiliki pengetahuan yang kurang dibanding dengan ibu yang memiliki pengetahuan yang sedang dan tinggi. Waktu yang digunakan dalam penelitian ini lama yaitu selama 7 bulan.

Pengetahuan yang kurang tentang anemia mempunyai pengaruh terhadap perilaku kesehatan khususnya ketika seorang wanita pada saat hamil, akan berakibat pada kurang optimalnya perilaku kesehatan ibu hamil untuk mencegah terjadinya anemia kehamilan. Ibu hamil yang mempunyai pengetahuan kurang tentang anemia dapat berakibat pada kurangnya konsumsi makanan yang mengandung zat besi selama kehamilan yang dikarenakan oleh ketidaktahuannya (Purbadewi \& Ulvie, 2013)

Tidak ada hubungan antara asupan protein ibu hamil terhadap status anemia ibu hamil dengan nilai $p=0.074$ dan nilai $r-311$. Nilai $r$ negatif menunjukkan semakin rendah asupan protein ibu hamil tentang anemia maka semakin tinggi status anemia ibu hamil.

Penelitian yang dilakukan oleh Bulkis et al (2013) juga menunjukkan bahwa tidak terdapat hubungan antara asupan protein dengan status hemoglobin ibu hamil dengan nilai $p=$ 0.64 .

Pada penelitian yang dilakukan oleh Sumarni (2006) menyatakan terdapat hubungan antara tingkat konsumsi protein dengan kadar hemoglobin dengan nilai $p=0.00$.

Perbedaan ini dikarenakan jumlah sampel, waktu penelitian, dan cara pengambilan data berbeda. Pada penelitian tersebut data diambil menggunakan metode Food Recall 24 jam dengan waktu penelitian yang lebih lama sehingga jumlah sampel yang di dapatkan lebih dari 50 sampel.

Protein memiliki korelasi dengan kadar hemoglobin. Protein dalam tubuh manusia berperan sebagai pembentuk butir-butir darah (hemopoiesis) yaitu pembentukan eritrosit dengan hemoglobin di dalamnya. Di dalam tubuh, zat besi tidak terdapat bebas, tetapi berasosiasi dengan molekul protein membentuk feritin

Ada hubungan antara asupan zat besi ibu hamil terhadap status anemia ibu hamil dengan nilai $p=0.189$ dan nilai $\mathrm{r}=-231$. Nilai $\mathrm{r}$ negatif menunjukkan semakin rendah asupan zat besi ibu hamil tentang anemia maka semakin tinggi status anemia ibu hamil.

Penelitian yang dilakukan oleh Bulkis et al (2013) bahwa tidak terdapat hubungan yang signifikan antara asupan Fe dengan status hemoglobin pada ibu hamil dengan nilai $p=0.25$.

Berbeda dengan penelitian yang dilakukan Sharon et al (2015) bahwa terdapat hubungan yang signifikan antara asupan zat besi dengan kejadian anemia dengan nilai $p=0.047$. Penelitian yang dilakukan Asmalilah et $a l$, mengatakan terdapat hubungan yang signifkan antara asupan zat besi dengan kadar hemoglobin ibu hamil dengan nilai $\mathrm{p}<0.05$. Perbedaan penelitian ini menggunakan metode recall 24 jam dan FFQ SQ dengan jumlah sampel ibu hamil yang lebih besar dan dianalisis dengan chi square.

Kurangnya zat besi di dalam tubuh dapat disebabkan oleh kurangnya konsumsi bahan makanan sumber zat besi besi atau makanan yang dikonsumsi sudah cukup namun memiliki bioavailabilitas besi yang rendah sehingga jumlah zat besi yang diserap kurang dan makanan yang dimakan 
mengandung zat penghambat absorbsi zat besi (Roosleyn, 2016).

Ada hubungan antara asupan vitamin $\mathrm{C}$ ibu hamil terhadap status anemia ibu hamil dengan nilai $p=0.052$ dan nilai $r$ - -336. Nilai $r$ negatif menunjukkan semakin rendah asupan vitamin $\mathrm{C}$ ibu hamil tentang anemia maka semakin tinggi status anemia ibu hamil.

Sejalan dengan hasil penelitian Ada hubungan antara asupan vitamin $\mathrm{C}$ terhadap status anemia ibu hamil trimester I. Sejalan dengan hasil penelitian yang dilakukan oleh Canthia et al (2015) pada siswi SMP di SMPN 3 Brebes menunjukkan terdapat hubungan antara asupan vitamin $\mathrm{C}$ dan kadar hemoglobin dengan $p=0.000$ dan $\mathrm{r}=$ 0.551 .

\begin{tabular}{ccc}
\multicolumn{2}{c}{ Berdasarkan penelitian yang } \\
dilakukan Yoni Astuti (2010)
\end{tabular} menyatakan bahwa terdapat hubungan yang signifikan antara asupan vitamin $\mathrm{C}$ dengan asupan besi $(\mathrm{r}=0.756)$ dan asupan besi dengan kadar $\mathrm{Hb}(\mathrm{r}=0.675)$. Hal ini bisa dikarenakan dalam pembentukan $\mathrm{Hb}$ membutuhkan zat besi , sedangkan absorbsinya membutuhkan vitamin C (Astuti, 2010).

Berbeda dengan penelitian yang dilakukan oleh Savitri et al (2015) bahwa tidak terdapat hubungan antara asupan vitamin $\mathrm{C}$ dengan kadar hemoglobin dengan nilai $p=0.77$. Perbedaan ini dikarenakan adanya perbedaan uji analisis yaitu menggunakan analisis chi square dan golongan yang berbeda yaitu pada mahasiswa di Riau yang berjumlah 50 orang.

Konsumsi vitamin C dapat membantu meningkatkan penyerapan zat besi. Asupan vitamin $\mathrm{C}$ rendah dapat memberikan implikasi terhadap kadar hemoglobin ibu hamil. Vitamin $\mathrm{C}$ mempunyai peran dalam pembentukan hemoglobin dalam darah, dimana vitamin $\mathrm{C}$ membantu penyerapan zat besi dari makanan sehingga dapat diproses menjadi sel darah merah kembali. Kadar hemoglobin dalam darah meningkat maka asupan makanan dan oksigen dalam darah dapat diedarkan ke seluruh jaringan tubuh yang akhirnya dapat mendukung kelangsungan hidup dan pertumbuhan janin (Fatimah, 2011).

Status zat besi didalam tubuh manusia tergantung pada penyerapan zat besi tersebut. Di antaranya yang dapat meningkatkan penyerapan besi atau enhancer dari sumber vitamin $\mathrm{C}$ seperti pada jeruk, pepaya serta sumber protein hewani tertentu contohnya daging sapi, daging ayam dan ikan . Vitamin $\mathrm{C}$ sebagai enhancer karena vitamin $\mathrm{C}$ membantu penyerapan besi non heme dengan merubah bentuk feri menjadi fero yang mudah diserap (Masthalina, Laraeani, \& Dahlia, 2015).

Ada hubungan antara asupan kalsium ibu hamil terhadap status anemia ibu hamil dengan nilai $p=0.003$ dan nilai $r=-497$. Nilai $r$ negatif menunjukkan semakin rendah asupan kalsium ibu hamil tentang anemia maka semakin tinggi status anemia ibu hamil.

Penelitian yang dilakukan oleh zamzam bahwa penambahan $127 \mathrm{mg} \mathrm{Ca}$ keju untuk makanan akan mempengaruhi penyerapan zat besi baik heme maupun non heme. Sedangkan tingkat variabilitas pengukuran penyerapan antara individu dan dalam setiap individu lebih besar pada besi non-heme daripada besi heme (Zamzam, 2016).

Penelitian yang dilakukan oleh Saddam (2015) dengan menganalisis data Riskesdas tahun 2007 pada wanita usia subur di Makassar menyetakan 
terdapat perbedaan rata - rata asupan kalsium pada wanita usia subur yang anemia dan tidak anemia.

Berbeda dengan penelitian Nurmalia yang menunjukkan tidak terdapat perbedaan yang signifikan antara kejadian anemia pada remaja putri yang asupan kalsiumnya lebih tinggi $(\mathrm{p}>0.05)$.

Kalsium merupakan salah satu zat gizi yang dapat menghambat penyerapan zat besi. Namun terdapat zat gizi lain seperti tannin, asam oksalat, dan serat. Pada penelitian ini tidak dilakukan penelitian tentang zat yang menghambat penyerapan zat besi sehingga zat tersebut dapat menjadi faktor perancu.

Protein, vitamin A, dan vitamin $\mathrm{C}$ merupakan nutrient pemacu absorbsi $\mathrm{Fe}$, sebaliknya kalsium merupakan penghambat absorbsi Fe. Selain kurangnya asupan Fe non heme, tingginya asupan kalsium akan berakibat menurunkan bioavailabilitas $\mathrm{Fe}$ yang dikonsumsi (Utari, 2012).

\section{E. Kesimpulan}

1. Dari 36 ibu hamil, sebanyak $66,67 \%$ tidak mengalami anemia di Puskesmas Kecamatan Setiabudi.

2. Dari 36 ibu hamil, sebanyak 58,3\% ibu hamil di Puskesmas Kecamatan Setiabudi memiliki pengetahuan baik.

3. Dari 36 ibu hamil, sebanyak 55,0\% memiliki asupan protein cukup di Puskesmas Kecamatan Setiabudi.

4. Dari 36 ibu hamil, sebanyak 94,4\% memiliki asupan zat besi kurang di Puskesmas Kecamatan Setiabudi.

5. Dari 36 ibu hamil, sebanyak $66,7 \%$ memiliki asupan vitamin C cukup di Puskesmas Kecamatan Setiabudi.

6. Dari 36 ibu hamil, dan seluruh ibu hamil memiliki asupan kalsium kurang dari AKG di Puskesmas Kecamatan Setiabudi.

7. Tidak terdapat hubungan antara pengetahuan ibu hamil terhadap status anemia pada ibu hamil di Puskesmas Kecamatan Setiabudi.

8. Terdapat hubungan yang signifikan antara asupan vitamin $\mathrm{C}$ dan kalsium terhadap status anemia pada ibu hamil di Puskesmas Kecamatan Setiabudi.

9. Tidak terdapat hubungan yang signifikan antara asupan protein dan zat besi terhadap status anemia pada ibu hamil di Puskesmas Kecamatan Setiabudi.

\section{Daftar Pustaka}

A.St.Bulkis, Jafar, N., \& Salam, A. (2013). Hubungan Pola Konsumsi dengan Status hemoglobin pada Ibu Hamil di Kabupaten Gowa Tahun 2013. Makassar: Universitas Hasanuddin.

Almatsier, S. (2009). Prinsip Dasar Ilmu Gizi. Jakarta: PT. Gramedia Pustaka Utama.

Astuti, C. H. (2010). Faktor - Faktor yang Berhubungan dengan Anemia Gizi Besi pada Ibu Hamil di Puskesmas Jalaksana Kuningan Tahun 2010. Jurnal Kesehatan Kartika, 51 - 58.

Astuti, Y. (2010). Hubungan antara Asupan Protein, Zat Besi dan Vitamin $\mathrm{C}$ dengan Kadar $\mathrm{Hb}$ pada Anak umur 7 - 15 Tahun di Desa Sidoharjo, Samigaluh, Kulon Progo. Mutiara Medika Volume 10 No. 2, 172 - 179.

Bahar, F. M. (2014). Hubungan Asupan Suplemen Kalsium pada Ibu Hamil dengan Panjang Bayi Saat Lahir di Wilayah Cengkareng 
Jakarta Barat. Nutrire Dianita Volume 6 No. 2, 83 - 98.

Bangun, M. F. (2013). Hubungan Pengetahuan Ibu Hamil tentang Anemia Defisiensi Besi terhadap Kepatuhan Mengkonsumsi Tablet Zat Besi. E-Journal FK USU Volume 1, 1 - 5.

Fatimah, S., Hadju, V., Bahar, B., \& Abdullah, Z. (2011). Pola Konsumsi dan kadar Hemoglobin pada Ibu Hamil di Kabupaten di Kabupaten Maros, Sulawesi Selatan. Makara Kesehatan Volume 15 No. 1, 31-36.

Hapsari, A. N. (2014). Hubungan Asupan Nutrisi dengan Kadar $\mathrm{Hb}$ pada Ibu Hamil di BPS Suratini Suwarno Surakarta. Kesmadaska, 21-27.

Hariwibowo, W. H. (2008). Asuhan Keperawatan Pada Klien dengan Gangguan Sistem Hematologi. Jakarta: Penerbit Salemba Medika.

Intifada, N. (2015). Hubungan Asupan $\mathrm{Fe}$, Zinc, dan Kalsium dengan Kejadian Anemia pada Remaja Putri Usia 13 - 18 Tahun di Pulau Jawa tahun 2007 (Analisis Data Sekunder Riskesdas tahun 2007). Jakarta: Universitas Esa Unggul.

Kemenkes. (2013, Oktober 20). Riset Kesehatan Dasar Tahun 2013. Jakarta: Kemenkes RI. Retrieved from

http://www.depkes.go.id/resource s/download/general/Hasil\%20Ris kesdas\%202013.pdf.

Lewa, A. F. (2016). Hubungan Asupan Protein, Zat Besi dan Vitamin C dengan Kejadian Anemia pada Remaja Putri di MAN 2 Model Palu. Jurnal Publikasi Kesehatan
Masyarakat Indonesia, Volume 3 No. 1, 26 -31.

Masrizal. (2007). Anemia Defisiensi Besi. Jurnal Kesehatan Masyarakat Volume II, 140 145.

Masthalina, H., Laraeani, Y., \& Dahlia, Y. P. (2015). Pola Konsumsi (Faktor Inhibitor dan Enhacer Fe Terhadap Status Anemia Remaja Putri) . KEMAS 11, 80 - 86.

Noversititi, E. (2012). Faktor - Faktor yang Berhubungan dengan Kejadian Anemia pada Ibu Hamil Trimester III di Wilayah Kerja Puskesmas Air Dingin Kota Padang 2012. Padang: Universitas Andalas.

Pradanti, C. M., M, Wulandari., \& K, Hapsari Sulistya. (2015). Hubungan Asupan Zat Besi (Fe) dan Vitamin $\mathrm{C}$ dengan Kadar Hemoglobin pada Siswi Kelas VIII SMPN 3 Brebes. Jurnal Gizi Universitas Muhammadiyah Semarang volume 4 No. 1, 24 29.

Prapitasari, E. (2013). Hubungan Antara Tingkat Pengetahuan Anemia dan Sikap Ibu Hamil dalam Mengkonsumsi Tablet Fe dengan Kejadian Anemia di WIlayah Kerja Puskesmas Kerjo Kabupaten Karanganyar. Jurnal Publikasi, 1 - 10. Retrieved from http://eprints.ums.ac.id/27088/22/ NASKAH_PUBLIKASI.pdf

Purbadewi, L., \& Ulvie, Y. N. (2013). Hubungan Tingkat Pengetahuan Tentang Anemia dengan Kejadian Anemia pada Ibu Hamil. Jurnal Gizi Universitas Muhamamdiyah Semarang Volume 2 No. 1, 31 - 39. 
Putri, R. A., Syamsianah, A., \& Mufnaetty. (2013). Hubungan Pengetahuan Tentang Anemia Gizi Besi Dengan Tingkat Konsumsi Protein Dan Zat Besi Pada Remaja Putri di Ponpes Asy-Syarifah Desa Brumbung Kabupaten Demak. Jurnal Gizi Universitas Muhammadiyah Semarang Volume 2, 21 - 29.

Rahardjo, E. K. (2003). Hubungan Pengetahuan, Sikap, dan Perilaku Mengenai Zat Besi terhadap Kejadian Anemia pada Ibu Hamil di Puskesmas Jatilawang Kabupaten Banyumas. Jurnal Pembangunan Perdesaan Volume 3 No. 1, 19-29.

Roosleyn, I. P. (2016). Strategi dalam Penanggulangan Pencegahan Anemia pada Kehamilan. Jurnal Ilmiah WIdya Volume 3 Nomer 3, 1-9.

Rottie, S. U. (2013). Hubungan Asupan Gizi dengan Kejadian Anemia pada Anak Sekolah Dasar di Kabupaten Bolaang Mongondow Utara. Ejournal Keperawatan Volume 1 no. 1.

Savitri, E. N., Fatmawati, \& Christianto, E. (2015). Hubungan Asupan Zat Besi, Vitamin C dan Tembaga dengan Kadar Hemoglobin pada
Mahasiswa Angkatan 2014 Fakultas Kedokteran Universitas Riau. JOM FK Volume 2, 1 - 16.

Sharon, G., Kapantow, N. H., \& Basuki, A. (2015). Hubungan Antara Asupan Zat Besi dan Protein dengan Kejadian Anemia pada SIswi SMP 10 Manado. Pharmacon Jurnal Ilmiah Farmasi, 327 - 332.

Sumarni, D. A. (2006). Hubungan Konsumsi Protein Hewani dan Zat Besi dengan Kadar Hemoglobin pada Balita 13 - 36 Bulan. The Indonesian Journal of Public Health volume 3, 19 - 23.

Utari, P. A. (2012). Prevalensi Anemia, Pengetahuan, dan Asupan Nutrisi pada Ibu Hamil di Wilayah Kerja Puskesmas Tampaksiring I, Kabupaten Gianyar, Bali. Jurnal Ilmiah Kedokteran Medicina, 83 $-88$.

WHO. (2015). The Global Prevalence of Anaemia in 2011. World Health Organization: Geneva.

Zamzam K (Fariba) Roughead, C. A. (2016). Initial uptake and absorption of nonheme iron and absorption of. The American Journal Of Clinical Nutrition, $419-425$ 